\begin{tabular}{|c|c|c|c|c|c|c|}
\hline \multirow{4}{*}{ Impact Factor: } & ISRA (India) & $=3.117$ & SIS (USA) & $=0.912$ & ICV (Poland) & $=6.630$ \\
\hline & ISI (Dubai, UAE & $=0.829$ & РИНЦ (Russia & $=\mathbf{0 . 1 5 6}$ & PIF (India) & $=1.940$ \\
\hline & GIF (Australia) & $=0.564$ & ESJI (KZ) & $=8.716$ & IBI (India) & $=4.260$ \\
\hline & JIF & $=1.500$ & SJIF (Morocco & $=5.667$ & OAJI (USA) & $=0.350$ \\
\hline
\end{tabular}

\section{SOI: 1.1/TAS DOI: 10.15863/TAS International Scientific Journal Theoretical \& Applied Science}

\author{
p-ISSN: 2308-4944 (print) \\ e-ISSN: 2409-0085 (online) \\ Year: 2019 \\ Issue: 04 \\ Volume: 72
}

\section{Published: $11.04 .2019 \quad$ http://T-Science.org}

QR - Issue

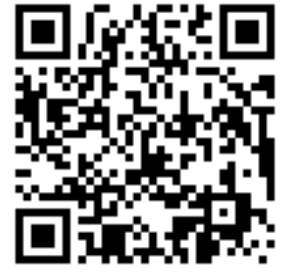

QR - Article

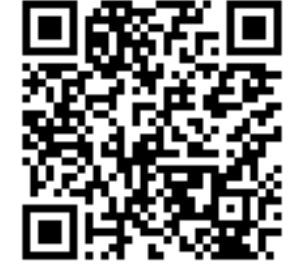

Dilfuza Sayfillaeva Lecturer at BukhSU,

Department of "National Idea, the Basics of Spirituality and Law education". dilfuza.sayfillaeva@mail.ru

\title{
THE HISTORY OF IDEOLOGICAL VIEWS THAT INFLUENCED THE FORMATION OF THE WORLDVIEW OF ABU HAMID GHAZALI
} \begin{abstract}
substance of god. in the work of the thinker "Ihya ulum ad-din". sunna, ismailits.

Language: English

\section{Introduction}

Today, society feels the power of historical documents which are invaluable from the moral point of view, and seeks to comprehend their historical essence.

The core idea contained in the ideological heritage of al-Ghazali, the call for perfection, the humanization of social relations, comprehensive concern for the spiritual development of man are successive and relevant today. They became a new orientation in covering the traditional problems of the Muslim history of the Middle century.
\end{abstract}

Abstract: This article is devoted to the great thinker of the Muslim East Abu Hamid Ghazali, as well as the history of the formation of his ideological views. The thinker lived during the development of science and the decline of Islamic values in the eyes of believers, due to the large number of religious groups. It is not for nothing that he is also called "Muhyid-Din" - the reviver of religion, since he managed to adapt Islam to the requirements of his time, without introducing innovations into religion. Ghazali acknowledges the doctrine of the inconvenience and eternity of the Quran; moreover, he assures that the Quran, Taurat (Pentateuch), Injil (Gospel) and Zabur (Psalms of David) are the same book of God, communicated through the revelation to the messengers of God, existing eternally in

In shaping his ideological worldview, Ghazali adopted from the Sufis their love for God, his knowledge of him, as well as his ethical views, which were close to the interests of religion. Thanks to Ghazali, the Sufi doctrine ceased to contradict the Qur'an, the Sunnah, and the Shari'ah. In matters of social justice, kindness, moral and ethical values, in the classification of sciences Ghazali proceeded from the teachings of Sufi Abu Talib Mackey, which are expressed

Abu Hamid Ghazali was not a philosopher in the full sense of the word, but he found the answer to all his questions and worked out his laws for the development and progression of human society. His views and theories have gone through many centuries and proved their right to actuality and existence in our time.

Key words: excrement, Ashari, church, islam, mutazilits, Selidzhukids, xanbalits, Nizamiya, xaridjits, shiiti,

Citation: Sayfillaeva, D. (2019). The history of ideological views that influenced the formation of the worldview of Abu Hamid Ghazali. ISJ Theoretical \& Applied Science, 04 (72), 82-84.

Soi: http://s-o-i.org/1.1/TAS-04-72-15 Doi: crosef https://dx.doi.org/10.15863/TAS.2019.04.72.15

\section{Materials and Methods}

The ideological inconsistency of the historical view of feudalism on the concept of society was one of the most important ideological prerequisites for the development of scientific interest to this issue. The studied period of time in which Abu Hamid Ghazali lived and worked in history is called the Middle centuries. The life of the scholar covers the second half of the XI - the beginning of the XII century. The 11 th century, historian V.V. Barthold, calls the century of the highest flourishing of Muslim culture and the beginning of its decline [3,183]. The life of Ghazali, which is one of the least studied periods in the medieval history of the Arab state, falls in the period of Seljuk rule. In the XI century, there is a decline in peasants uprisings.

"One of the most important phenomena in the socio-economic and political life of the Arab caliphate during this period was the arrival in the territory of the state of a large mass of Turkic nomads. One of the Turkmen - Oguz clans - the Seljuks - later created a 


\begin{tabular}{|c|c|c|c|c|c|c|}
\hline \multirow{4}{*}{ Impact Factor: } & ISRA (India) & $=3.117$ & SIS (USA) & $=0.912$ & ICV (Poland) & $=6.630$ \\
\hline & ISI (Dubai, UAE & $=0.829$ & РИНЦ (Russia) & $=0.156$ & PIF (India) & $=1.940$ \\
\hline & GIF (Australia) & $=0.564$ & ESJI (KZ) & $=8.716$ & IBI (India) & $=4.260$ \\
\hline & JIF & $=1.500$ & SJIF (Morocco & $=5.667$ & OAJI (USA) & $=0.350$ \\
\hline
\end{tabular}

powerful state in the territory of the caliphate "[2,17]. During this period, the state took measures for the development of urban life, trade and industry. The period of the Seljuks was also characterized by the fact that they were patrons of poetry and science. Many scholars and poets wrote their works at their court.

The Seljuks were devout Muslims (Sunnis) and tried to destroy Shiism, which was the focus of Abu Hamid Ghazali, who was supported by the Vizier, as well as the de facto ruler in the country Nizam ulMulk (1063-1092). These were the years of economic and cultural growth. Nizam ul-Mulk was the patron of science, literature and art. In Basra, Herat, Nishapur, Bukhara, Samarkand and Baghdad, he opened religious schools (Nizamiyya) [2,19]. This time was also a period of fierce religious struggle, the activity of various sects, professing the views adopted from other beliefs, intensified. As Bartold V.V. points out, the struggle was already fought not between landlords and farmers, but between castles and cities [3.185]. Under the castles, the scientist is referring to the Ismailis (assassins). * The Ismailis were supported by the south-western part of Khorasan (Kuhistan), where $2 / 3$ of all Ismailits castles were located, and the fortress of Alamut was the seat of the head of the sect. If the Fatimid dynasty * initially fully supported the Ismailis, then at the end of the XI century there was a gap between them. The complex socio-political and social life in the Caliphate, along with the Ismaili sect, gave rise to a plurality of different religious and political trends. Russian academic of Islam S.M. Prozorov in his book reveals the ideological origins of these religious movements. In the 7- 8 th centuries, among Muslims there were differences in the understanding of faith and in relation to the person who committed a serious sin. The most radical position was occupied by Kharijites (al-Khavarij). They argued that a person who committed a serious sin ceases to be a Muslim and becomes an unbeliever (kafir) [4, 7]. The Muridzhits (al-murdzhia) proclaimed the actions of man as secondary, and those who preserve the purity of faith in the heart, despite the sin committed, are a true Muslim.

Mutazilites (al-mutazil) occupied the middle position. They developed the doctrine of "average condition" (al-manzil bayn-1-manzilatain) of a Muslim and called for a neutral position in conflicts. First-generation Muslims argued about the predestination of human actions and actions. A group of Muslims who believed in divine predestination received the name of the Dzhabritov (al-Jabriya). Later in Islam, the Qadarite (al-Qadariya) was born, relying on human freedom in their actions, and their successors were the Mu'tazilites. Muridzhits remained neutral in this dispute. Also, the fact of the origin of the Koran was considered a controversial issue. Particularly distinguished in this dispute were the advocates of the creation of the Qur'an - the mutazilites, and its incompatibility - the hanbalites $[4,10]$.

But at the root of all these disputes and unresolved issues remained the problem of sovereign power. Each religious grouping tried to convince the population of the Caliphate of the truth of their dogmas, which especially became the ideological slogan of the struggle of "righteous" movements against "unrighteous rulers", namely the Kharijite and Shiite movements $[4,10]$. The reason for such disputes was the discrepancy about the predestination of human destiny. The early Muslims were convinced that the life of a person with all his works and thoughts was premature. With the emergence of such disputes, the question of what is true faith arose before Muslims with all the urgency, which contributed to the appearance of the antonyms of "orthodoxy". As S.M. Prozorov notes, an expert on Islam as an ideological system, the reason for these disputes was that Islam did not have an institution for the legalization of dogmas like the Ecumenical Councils, and that Islam (Sunni) did not know the sole infallible chapter churches $[4,10,11]$.

Islam rejected the existence of the institution of the church, along with the state. The interpretation of the dogmas of religion was not the responsibility of the caliph or state institutions. Public opinion involved private individuals - religious leaders (ulama and faqih). The doctrines of these ulamas, which the Caliph adopted, became generally accepted and official only for a limited period of time. In other words, Islam does not recognize the mediation between God and the believers, the mediation that the Church performs in Christianity $[4,11]$.

Already in the middle of the 8th century, Islam was filled with various theological and legal schools. Representatives of one school could be hostile to certain views of another, and at the same time agree with them on other matters. For example, the dirarites agreed on some issues of dogma with Sunnis, in others with mutazilites, in the third with najdzharits, while at the same time diverging with them on a number of other issues.

At the beginning of the 10th century, the theological school of Asharites (al-Ashariya) succeeded in creating a compromise doctrine on predestination and freedom of human will. "While recognizing Allah as the creator of all things, the Asharites at the same time argued that a person" acquires "his actions, participates in their accomplishment" [4,9]. This doctrine later became the subject of heated debate among Muslims. Asharism had a great influence on Abu Hamid Ghazali. He became one of the ideological origins of the formation of the concept of the thinker. The founder of asharism is Ali b. Ismail Abu-1-Hassan al-Ashari - the famous Muslim theologian - Mutakallim *. A fundamental step in the life of Ashari was his public renunciation of the teachings of the Mu'tazilites. 


\begin{tabular}{|c|c|c|c|c|c|c|}
\hline \multirow{4}{*}{ Impact Factor: } & ISRA (India) & $=3.117$ & SIS (USA) & $=0.912$ & ICV (Poland) & $=6.630$ \\
\hline & ISI (Dubai, UAE & $=0.829$ & РИНЦ (Russia & $=\mathbf{0 . 1 5 6}$ & PIF (India) & $=1.940$ \\
\hline & GIF (Australia) & $=0.564$ & ESJI (KZ) & $=8.716$ & IBI (India) & $=4.260$ \\
\hline & JIF & $=1.500$ & SJIF (Morocco & $=5.667$ & OAJI (USA) & $=0.350$ \\
\hline
\end{tabular}

At the beginning of his life, the theologian was a jealous advocate of the Mutazilites, but after about a quarter of a century, Ashar was known as Nemutazilite, who converted to Shafi'i madhhab. * Academician S. Prozorov, who studied al-Ashari's work as a doxographic source, claims that the theologian was in the center of the ideological struggle, which led among themselves representatives of different directions and schools of Islam for the approval of their teachings only "faithful." In his writings Ashari paid more attention to the Qur'an and the Sunnah. In these major sources of Islam, the theologian saw a rationalistic method of resolving disputes - the basis of al-kalam, and considered the Mutakallim true Sunnis. If Ghazali adopted his view on the Qalam from Ashari, then the Shafiite mazhab helped him in forming his views on fiqh *.

At that time, the political situation in the Caliphate was aggravated, the government was not determined about the theological and legal sense (mazhab) of the state religion and Abu Hamid Ghazali's speech about the spiritual revival of the Muslim community were by the way. Al-Ghazali's desire to reconcile opposing ideological tendencies in a society dominated by religion is explained by his desire to alleviate the social and ideological contradictions that have a destructive effect on the foundations of the Caliphate.

The theologian al-Ghazali, appointed at one time to a leadership position at the Nizamiya Madrasa in
Baghdad, could not help but understand that his efforts, both in the field of teaching and composing, should be aimed at protecting the centralized state, from the types of the incarnation on earth of divine will . Nizam ul-Mulk, the patron saint of Mohammed Ghazali, deliberately appointed him to the post of rector of Nizamiya in Baghdad, hearing his speech against religious sects. Vazir Malik Shah saw in the face of the young Ghazali a "reviver" and conciliator who would balance religious conflicts.

\section{Conclusion}

Summarizing the above, it should be pointed out that, despite his short life, Abu Hamid Ghazali left a huge legacy as a guide for future generations. Awarded the high title of Imam, "Islam Cause" the thinker proved the consistency of his doctrine, as well as its significance for Muslim believers, who preferred his views to others. Studying the life of Ghazali shows that his activity was not aimed at conquering his vocation. Ghazali thoroughly studied all the doctrines that existed at that time, and could conduct disputes on all topics.

The breadth and versatility of the thinker's views, his belief in the improvement of human nature, his struggle with various sects that undermined the foundations of the Caliphate, and efforts to reconcile Sunnism and Sufism make Ghazali one of the foremost thinkers of the East of the late 11th - early 12 th centuries of great interest for modern researchers.

\section{References:}

1. Abu Hamid al-Ghazali (1980). The resurrection of the sciences of faith. Translation from Arabic, research and comment by V.V. Naumkin. Moscow.

2. Bartold, V. V. (2002). Works on the history of Islam and the Arab Caliphate. T.VI. "Eastern Literature", Russian Academy of Sciences. Moscow.

3. Prozorov, S. M. (2004). Islam as an ideological system. Moscow: Institute of Oriental Studies, St. Petersburg Phil. Eastern literature.

4. Nasyrov, I. R. (n.d.). Al-Ghazali-"The argument of Islam." http://islamdag.ru.//lichnosti/
5. Safarova, N. (2009). Terrorism: (tarikhiū-falsafǐ̆ tahlil). Toshkent: Noshir. //Library of Congress Washington, DC 20540 United States.; http://searchworks.stanford.edu/

6. Yunusova, G. S. (n.d.). The viewpoints of Abdulkadir Giloni about the "human"and man conceptions. Philadelphia, USA. ISJ Theoretical \& Applied Science, 176-178

7. Safarova, N., \& Aslanov, N. (2013, December). New Research Approach: Cognitive Abilities of a person. International Journal of Health Sciences. Vol. 1 No. 1. http://ijhsnet.com/vol-1no-1-december-2013-ijhs 